\title{
FORMATION PROCESS AND CHARACTERIZATION OF SPHERE-LIKE BACTERIAL CELLULOSES IN AGITATED CULTURE IN TWO DIFFERENT MEDIA
}

\author{
JICAI BI, ${ }^{* * *}$ SIXIN LIU ${ }^{* *, * * *}$ and CONGFA LI ${ }^{* *}$ \\ "School of Food Science and Technology, Henan Institute of Science and Technology, \\ Xinxiang, 453003, China \\ ${ }^{* *}$ College of Food Science and Engineering, Hainan University, Haikou 570228, China \\ ${ }^{* * * *}$ College of Science, Hainan University, Haikou 570228, China \\ $\square$ Corresponding authors: S. Liu, sixinliu@126.com \\ C.Li, congfa@vip.163.com
}

Received January 19, 2020

\begin{abstract}
The formation process of sphere-like bacterial cellulose was investigated using Komagataeibacter nataicola Y19 in agitated culture in Hestrin-Schramm medium (HS) and fermented coconut water medium (FCW), and the BC particles obtained were characterized. Two kinds of BCs were obtained, and their morphology changed from filamentous BC on the $1^{\text {st }}$ day to final solid sphere-like BC on the $7^{\text {th }}$ day, and accordingly, the size of internal pores decreased gradually, the degree of crystallinity increased gradually from $76.44 \%$ to $84.23 \%$ (HS) or from $62.11 \%$ to $79.53 \%(\mathrm{FCW})$, $\mathrm{I}_{\alpha}$ decreased gradually from $76.63 \%$ to $70.84 \%$ (HS) or from $70.69 \%$ to $55.74 \%$ (FCW) and $\mathrm{I}_{\beta}$ increased gradually, the thermal stability increased and the maximum decomposition temperature $\left(T_{\max }\right)$ rose from $316.92{ }^{\circ} \mathrm{C}$ to $339.08{ }^{\circ} \mathrm{C}$ (HS) or from $305.07{ }^{\circ} \mathrm{C}$ to $334.44{ }^{\circ} \mathrm{C}(\mathrm{FCW})$.
\end{abstract}

Keywords: sphere-like bacterial cellulose, formation process, agitated culture, Hestrin-Schramm medium, fermented coconut water medium, Komagataeibacter nataicola

\section{INTRODUCTION}

Cellulose is a very important and fascinating biopolymer, and an almost inexhaustible and sustainable natural polymeric raw material, ${ }^{1}$ which is of special importance both to industries and in our daily life. It is an important structural component of the primary cell wall of green vascular plants, consisting of a linear homopolysaccharide containing several hundred to over ten thousand repeating units of D-glucose linked together with a $\beta-1,4$ linkage. ${ }^{2}$ Cellulose could also be secreted by Komagataeibacter, Gluconacetobacter, Rhizobium, Agrobacterium, Rhodobacter and Sarcina. ${ }^{2-4}$

As bacterial cellulose exhibits several unique properties, such as high mechanical strength, high crystallinity, high water absorption capacity, high porosity, high purity, moldability, biodegradability and excellent biological affinity, an increasing number of researchers have focused on its applications in various fields in recent years. The water uptake of BC is significant, it can absorb more than $99 \%$ water. Due to its properties, BC has been investigated for a variety of applications, such as in acoustic transducer diaphragms, paper manufacturing, filtration, pharmaceutical applications, food applications, electrically conductive materials et al. ${ }^{2,5-10}$

Sphere-like BC has a wide application prospect due to its regular shape, large specific surface area and no need for mechanical cutting. It can be produced in agitated culture, but this has caused many problems, such as the accumulation of cellulose-negative $\left(\mathrm{Cel}^{-}\right) \quad$ mutants, ${ }^{11}$ non-Newtonian viscosity behavior and insufficient oxygen supply during BC production. ${ }^{12-14}$ Despite these problems, the agitated culture might be the most suitable technique for large scale production. ${ }^{5,15}$ In our 
laboratory, we obtained a series of $\mathrm{BC}$ with unique solid sphere-like structures, synthesized by a specific strain - Komagataeibacter nataicola Y19. Despite previous research, the formation process of sphere-like $\mathrm{BC}$ grown from micro-fibre to big solid sphere-like $\mathrm{BC}$ remains unclear. In the present study, the formation process of sphere-like bacterial cellulose was investigated using $K$. nataicola Y19 in Hestrin-Schramm medium (HS) and fermented coconut water medium (FCW) in agitated culture, and the $\mathrm{BC}$ particles obtained were characterized.

\section{EXPERIMENTAL}

Micro-organisms, media and fermentation
conditions

K. nataicola Y19 was used in the study and stored in the Lab of Applied Microbiology, College of Food Science and Technology, Hainan University. Hestrin-Schramm (HS) medium ${ }^{16}$ with $\mathrm{pH}$ adjusted to 6.0 and fermented coconut water (FCW) medium (3 $\mathrm{g} / \mathrm{L}\left(\mathrm{NH}_{4}\right) \mathrm{SO}_{4}, 0.3 \mathrm{~g} / \mathrm{L} \mathrm{MgSO}_{4}, 0.3 \mathrm{~g} / \mathrm{L} \mathrm{KH}_{2} \mathrm{PO}_{4}, 70 \%$ $\mathrm{v} / \mathrm{v}$ fermented coconut water, sugar adjusted to $5{ }^{\circ} \mathrm{Brix}$, $\mathrm{pH}$ adjusted to 4.0) were added with Congo red, which was used as an indicator for bacterial cellulose generation in HS and FCW, and could provide the label for a rapid growth of sphere-like $\mathrm{BC} .^{17}$ The main cultures were grown in a $200 \mathrm{~mL}$ Bunsen beaker at rotational speeds of $130 \mathrm{rpm}$ (our previous experiments had shown that sphere-like BC can be stably produced at this speed) for 7 days at $30{ }^{\circ} \mathrm{C}$. The synthesized cellulose was separated by filtration and washed with $1 \%$ sodium hydroxide solution to remove the cells and the media, followed by washing with distilled water till pH 7.

\section{Analysis of properties of bacterial cellulose}

Freeze-dried bacterial cellulose samples were coated with platinum and viewed under a scanning electron microscope in the usual way (S-3000n, Hitachi, Japan). ${ }^{18-20}$

I $\alpha$ mass fractions were calculated using absorbency data from recorded FTIR spectra (256 scans, $2 \mathrm{~cm}^{-1}$ in the range from 4000 to $400 \mathrm{~cm}^{-1}$ ). The following formula described by Yamamoto et al. was used in calculations: ${ }^{21} f_{\alpha}=2.55 f^{\mathrm{R}}{ }_{\alpha}-0.32$, where $f^{\mathrm{R}}{ }_{\alpha}$ of cellulose can be calculated as $A_{\alpha} /\left(A_{\alpha}+A_{\beta}\right)$, where $A_{\alpha}$ and $A_{\beta}$ are absorbencies at $750 \mathrm{~cm}^{-1}$ and $710 \mathrm{~cm}^{-1}$, respectively.

The crystal structure of the bacterial cellulose samples was analyzed by an X-ray diffractometer (D8-Advance, Bruker AXS) at ambient temperature, using $\mathrm{Cu} \mathrm{K} \alpha(1.5406 \AA)$ radiation between $2 \theta=5^{\circ}$ $60^{\circ}$ at 1 second step size and increment of 0.01 degree with $0.5^{\circ}$ or $1.0 \mathrm{~mm}$ of divergent and anti-scattering slit. The relative crystallinity index was calculated according to the formula constructed by Segal: ${ }^{22} \mathrm{Cr} \mathrm{I}=$ $\left(I_{200}-I_{\text {am }}\right) / I_{200}$, where $I_{200}$ is the overall intensity of the peak at $2 \theta$ of about $22.9^{\circ}$ and $I_{\mathrm{am}}$ is the intensity of the baseline at $2 \theta$ of about $18^{\circ} .^{23}$ The crystal size was calculated using the Scherrer equation: ${ }^{24} D_{\mathrm{hkl}}=$ $K \lambda / \beta_{\mathrm{hkl}} \cos \theta_{\mathrm{hkl}}$, where $\beta$ is the breadth of the peak of a specific phase (hkl), $K$ is a constant that varies with the method of taking the breadth $(0.89<K<1), \lambda$ is the wavelength of incident X-rays $(\lambda=1.5406 \AA), \theta$ is the center angle of the peak, and $D$ is the crystallite length (size).

The thermal properties of the bacterial cellulose samples were analyzed by a thermogravimetric analyzer (TGA) machine (SDT Q600, TA Instruments). The weight loss was recorded under $\mathrm{N}_{2}(40 \mathrm{~mL} / \mathrm{min})$ atmosphere in the range of $50{ }^{\circ} \mathrm{C}$ and $\sim 500{ }^{\circ} \mathrm{C}$, at a heating rate of $10{ }^{\circ} \mathrm{C} / \mathrm{min}$, at which point only ashes remained. ${ }^{25,26} \mathrm{~A}$ weight loss curve and its derivative curve were thus obtained to determine decomposition temperatures and associated weight losses. ${ }^{27,28}$

\section{RESULTS AND DISCUSSION}

Macro- and micro-morphology of BCs during culture process

Light solid sphere-like BC particles were accumulated in the agitated culture from the $1^{\text {st }}$ day to $7^{\text {th }}$ day (Fig. 1). Congo red could stain the cellular tissue due to its strong affinity to cellulose fibers, ${ }^{26}$ and therefore it was used to observe the formation process of sphere-like BC. In addition, Congo red had no influence on the macroscopic morphology of the sphere-like BC, which was different for the two media. In HS, the sphere-like BC began to form after 24 hours in the agitated culture, with a visible fine filamentous BC being observed (Fig. $1 \mathrm{HS}$ ). On the $1^{\text {st }}$ day, the BC looked like loose filamentous and colloidal particles, consisting of several coarse filaments as basic framework (Fig. 2 HS). Also, the smaller filamentous structure was distributed around the basic framework. On the $2^{\text {nd }}$ day, BC "grew" larger and a series of non-uniform loose sphere-like BC particles formed. On the $3^{\text {rd }}$ day, more sphere-like $\mathrm{BC}$ particles, with larger diameter, could be seen, and the original initial filamentous framework was surrounded by gelatinous BC. From the $4^{\text {th }}$ to the $7^{\text {th }}$ day, the sphere-like BC particles grew bigger and bigger, with the diameters of the particles being about 5-10 mm, however the number of sphere-like BC particles did not change. Meanwhile, in FCW, the BC particles observed had a diameter of 0.05-0.1 $\mathrm{cm}$, of irregular point-like shape on the $1^{\text {st }}$ day 
(Fig. 1 FCW). We also observed the formation of new "born" fiber and oval shaped bacteria surrounded by BC by dying with Congo red (Fig. $2 \mathrm{FCW})$. On the $2^{\text {nd }}$ day, more punctate particles with a larger diameter, of 0.1-0.2 cm, formed, and even some clusters formed. On the $3^{\text {rd }}$ day, the small particles combined into larger particles with the diameter of $0.2-0.3 \mathrm{~cm}$. From the $4^{\text {th }}$ day to the $7^{\text {th }}$ day, the particles continued to "grow", reaching a final diameter of $0.6-0.8 \mathrm{~cm}$. Every particle was wrapped by 2-6 small particles.

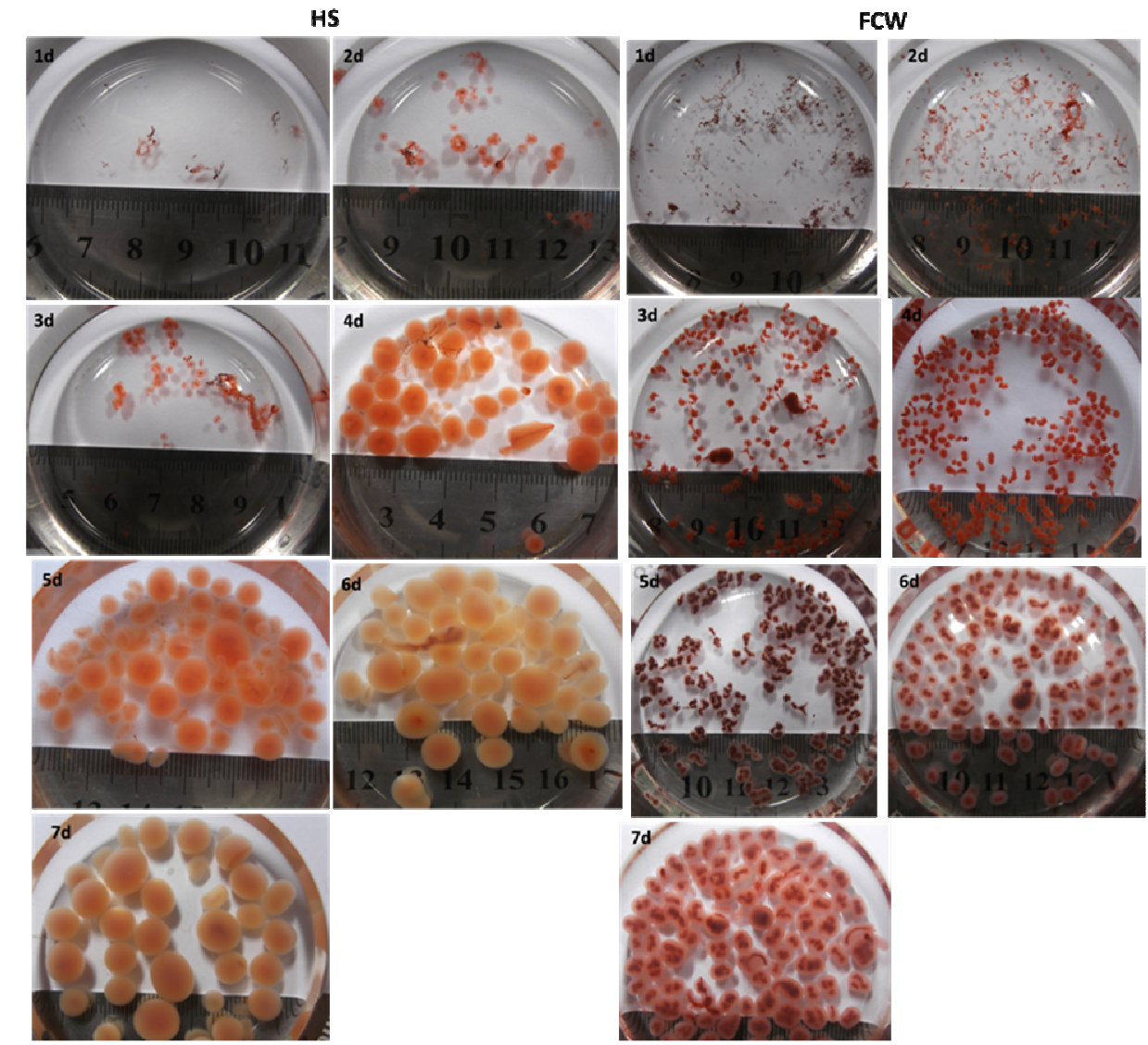

Figure 1: Optical images of BC samples prepared in agitated culture in HS (right) and FCW (left) media from the $1^{\text {st }}$ to the $7^{\text {th }}$ day with Congo red staining

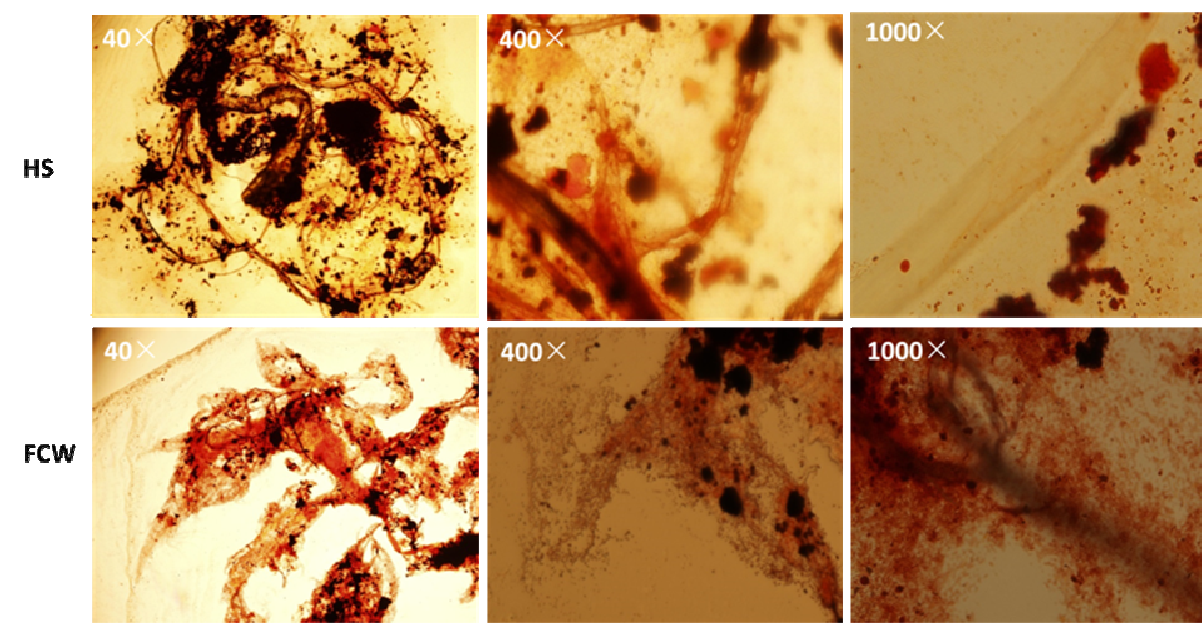

Figure 2: Optical microscopic observation of filamentous BC prepared in agitated HS (above) and FCW (below) media on the $1^{\text {st }}$ day with Congo red staining 


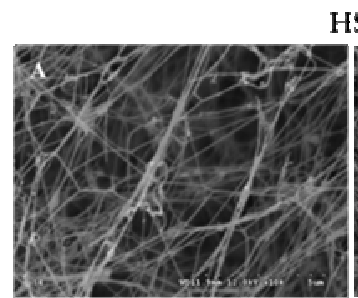

HS
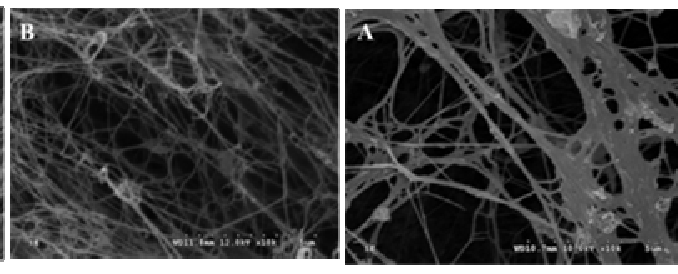

FCW
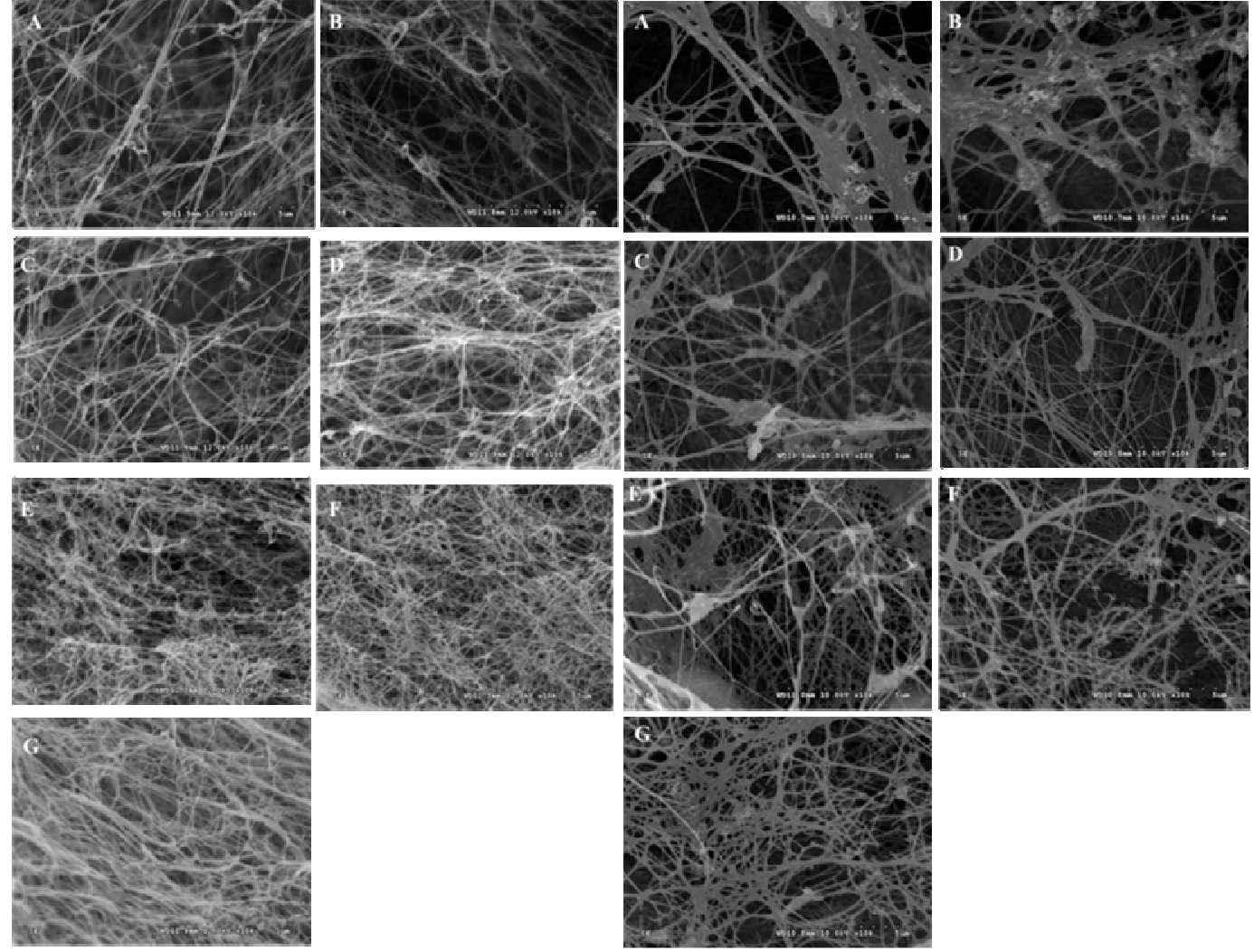

Figure 3: SEM images of BC samples without Congo red prepared in agitated culture in HS (right) and FCW (left) media, from day 1 to day 7 (A to G, respectively)

In order to observe the BC microfibrils, SEM images were obtained. Our results illustrated a disordered reticulated structure, consisting of ultrafine fibrils of 50-100 nm width. The width of the ultrafine fibrils produced during the culture process was almost the same. In HS medium (Fig. $3 \mathrm{HS}$ ), filamentous $\mathrm{BC}$ on the $1^{\text {st }}$ day was the loosest and largest in terms of pore size, while the solid sphere-like BC of the $7^{\text {th }}$ day was the most compact and with the smallest pore size. SEM results illustrate that, from day 1 to day 7 , the fiber bundles became more and more compact, while the pore size reduced gradually. Based on the observations mentioned above, the sphere-like $\mathrm{BC}$ became larger in diameter and more compact, with reduced pore size along the culture process. As for FCW (Fig. $3 \mathrm{FCW}$ ), the filamentous BC under SEM observation on day 1 to day 2 showed loosely arranged fiber bundles, with larger pore size. The fiber bundles were intertwined. From day 3 to day 7, the number of the fiber bundles increased, while the pore diameter and the degree of adhesion reduced gradually.

We obtained two kinds of $\mathrm{BCs}$ and their morphology changed from filamentous on the $1^{\text {st }}$ day to solid sphere-like BC on the $7^{\text {th }}$ day, and accordingly, the size of internal pores decreased gradually. Sheykhnazari et al. used Gluconacetobacter xylinus BPR 2004 to investigate the effects of growth time on $\mathrm{BC}$ structure. ${ }^{29}$ They found that increasing the growth time up to 7 days could improve the number of microfibril branches crossing to each other. The number of bundles increased, while further prolonging the growth time up to 21 days led to weaker microfibrils network. ${ }^{29}$ The $\mathrm{BC}$ microfibrils produced in agitated culture were more twisted and curlier than those obtained in stationary culture, maybe because of the shear force of the turbulent current in agitated broth. ${ }^{30,31}$ The highly hydrophilic $\mathrm{BC}$ surface can promote a homogenous distribution of drugs within the $\mathrm{BC}$ membranes. ${ }^{32}$ Also, it has been observed that new modifications did not alter the existing favorable properties of solid sphere-like BC, while adding novel advantageous features to the material. ${ }^{33}$ Thus, solid sphere-like BC was found suitable for the development of drug release materials. 
Bacterial cellulose

HS

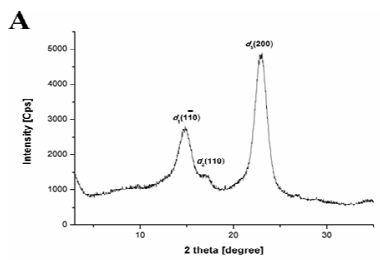

FCW
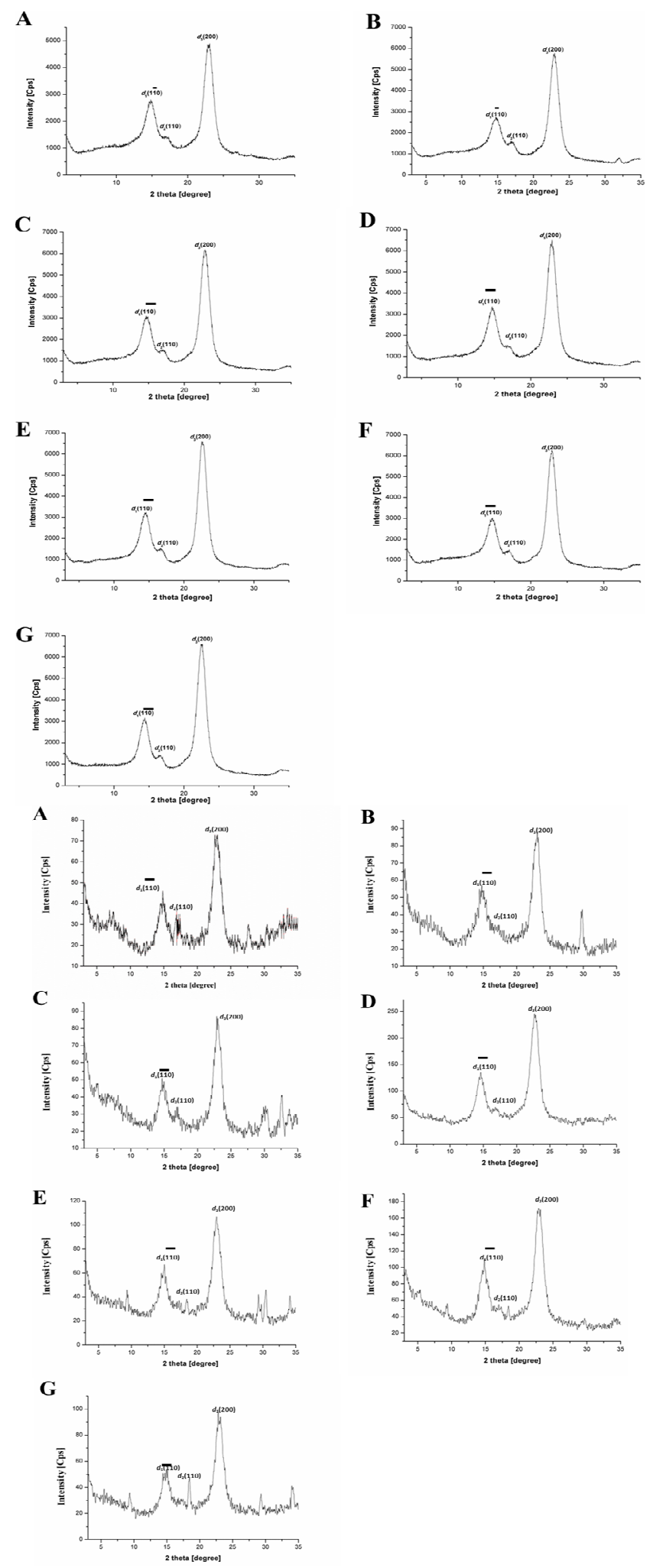

Figure 4: X-ray diffraction patterns of BCs without Congo red staining, prepared in agitated culture in HS (left) and FCW (right) media from day 1 to day 7 (A to G, respectively). Three typical diffraction peaks occurring in the region of $10-25^{\circ}$ were labeled as $d_{1}, d_{2}$ and $d_{3}$ 
Table 1

$D$-spacings, crystallite sizes and percent crystallinity of BCs prepared in agitated culture in HS and FCW media from day 1 to day 7

\begin{tabular}{|c|c|c|c|c|c|c|c|c|}
\hline \multirow[t]{2}{*}{ BC sample } & \multicolumn{3}{|c|}{$d$-Spacings $(\AA)$} & \multirow{2}{*}{$\begin{array}{c}\text { Difference in } \\
2 \theta \text { angle } \\
\text { peak1-peak2 }\end{array}$} & \multicolumn{3}{|c|}{$\begin{array}{c}\text { Crystallite sizes } \\
(\mathrm{nm})\end{array}$} & \multirow{2}{*}{$\begin{array}{c}\text { Percent } \\
\text { crystallinity }(\%) \\
c\end{array}$} \\
\hline & $d_{1}$ & $d_{2}$ & $d_{3}$ & & $c r_{1}$ & $\mathrm{Cr}_{2}$ & $\mathrm{Cr}_{3}$ & \\
\hline $\mathrm{BC}-1^{\mathrm{st}}$ day $(\mathrm{HS})$ & 6.23 & 5.18 & 3.86 & 2.151 & 8.2 & 11.4 & 8.4 & 76.44 \\
\hline $\mathrm{BC}-2^{\text {nd }}$ day $(\mathrm{HS})$ & 6.07 & 5.15 & 3.87 & 2.177 & 8.5 & 12.3 & 8.5 & 80.27 \\
\hline $\mathrm{BC}-3^{\text {rd }}$ day (HS) & 6.03 & 5.19 & 3.88 & 2.225 & 8.7 & 13.8 & 8.6 & 81.27 \\
\hline $\mathrm{BC}-4^{\text {th }}$ day (HS) & 6.02 & 5.29 & 3.34 & 2.301 & 8.7 & 14.4 & 8.6 & 81.61 \\
\hline BC- $-5^{\text {th }}$ day (HS) & 6.00 & 5.33 & 3.93 & 2.424 & 8.9 & 14.5 & 8.7 & 82.78 \\
\hline BC- $6^{\text {th }}$ day (HS) & 5.96 & 5.16 & 3.88 & 2.462 & 8.9 & 14.7 & 8.7 & 83.43 \\
\hline BC $-7^{\text {th }}$ day (HS) & 5.92 & 5.19 & 3.87 & 2.476 & 9.2 & 15.3 & 8.7 & 84.23 \\
\hline $\mathrm{BC}-1^{\text {st }}$ day $(\mathrm{FCW})$ & 6.19 & 5.16 & 3.89 & 2.22 & 3.9 & 4.8 & 4.3 & 62.11 \\
\hline $\mathrm{BC}-2^{\text {nd }}$ day $(\mathrm{FCW})$ & 6.11 & 5.17 & 3.87 & 2.33 & 5.5 & 6.2 & 5 & 64.02 \\
\hline $\mathrm{BC}-3^{\text {rd }}$ day $(\mathrm{FCW})$ & 6.08 & 4.82 & 3.86 & 2.35 & 6.1 & 7.6 & 5.1 & 70.06 \\
\hline $\mathrm{BC}-4^{\text {th }}$ day $(\mathrm{FCW})$ & 6.03 & 5.09 & 3.86 & 2.37 & 7.5 & 10 & 5.8 & 72.14 \\
\hline $\mathrm{BC}-5^{\text {th }}$ day $(\mathrm{FCW})$ & 6.01 & 5.21 & 3.85 & 2.45 & 8 & 10 & 6 & 77.64 \\
\hline BC- $6^{\text {th }}$ day $(\mathrm{FCW})$ & 5.95 & 5.25 & 3.91 & 2.53 & 10 & 11.6 & 7.6 & 78.61 \\
\hline BC- $7^{\text {th }}$ day $(\mathrm{FCW})$ & 5.87 & 4.79 & 3.84 & 2.67 & 10 & 13.1 & 8.4 & 79.53 \\
\hline
\end{tabular}

Table 2

Cellulose $\mathrm{I}_{\alpha}$ and $\mathrm{I}_{\beta}$ contents and crystallinity index of BCs prepared in agitated culture in HS and FCW medium from $1^{\text {st }}$ to $7^{\text {th }}$ day

\begin{tabular}{|c|c|c|c|}
\hline BC sample & $\mathrm{I}_{\alpha}(\%)$ & $\mathrm{I}_{\beta}(\%)$ & $\begin{array}{l}\text { IR crystallinity index } \\
\left(\text { Abs. at } 1428 / 896 \mathrm{~cm}^{-1}\right)\end{array}$ \\
\hline $\mathrm{BC}-1^{\mathrm{st}}$ day $(\mathrm{HS})$ & 76.63 & 23.37 & 4.23 \\
\hline $\mathrm{BC}-2^{\text {nd }}$ day $(\mathrm{HS})$ & 76.58 & 23.42 & 4.46 \\
\hline BC $-3^{\text {rd }}$ day (HS) & 74.46 & 25.54 & 4.93 \\
\hline $\mathrm{BC}-4^{\text {th }}$ day (HS) & 72.83 & 27.17 & 5.22 \\
\hline BC $-5^{\text {th }}$ day (HS) & 72.75 & 27.25 & 5.88 \\
\hline BC- $6^{\text {th }}$ day (HS) & 71.71 & 28.29 & 6.40 \\
\hline BC- $7^{\text {th }}$ day (HS) & 70.84 & 29.16 & 6.61 \\
\hline $\mathrm{BC}-1^{\text {st }}$ day $(\mathrm{FCW})$ & 70.69 & 29.31 & 3.52 \\
\hline $\mathrm{BC}-2^{\text {nd }}$ day $(\mathrm{FCW})$ & 68.09 & 31.91 & 3.68 \\
\hline $\mathrm{BC}-3^{\text {rd }}$ day $(\mathrm{FCW})$ & 67.52 & 32.48 & 4.43 \\
\hline $\mathrm{BC}-4^{\text {th }}$ day $(\mathrm{FCW})$ & 60.51 & 39.49 & 5.04 \\
\hline $\mathrm{BC}-5^{\text {th }}$ day $(\mathrm{FCW})$ & 59.00 & 41.00 & 5.50 \\
\hline BC- $6^{\text {th }}$ day $(\mathrm{FCW})$ & 56.03 & 43.97 & 6.17 \\
\hline BC- $7^{\text {th }}$ day $(\mathrm{FCW})$ & 55.74 & 44.26 & 6.33 \\
\hline
\end{tabular}


Bacterial cellulose

HS

A

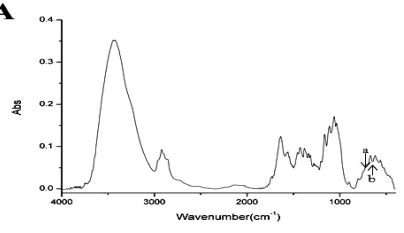

C

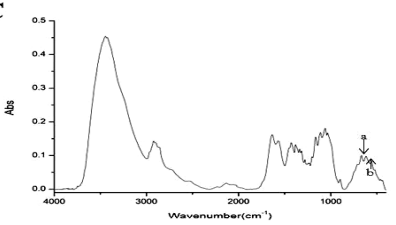

$\mathbf{E}$

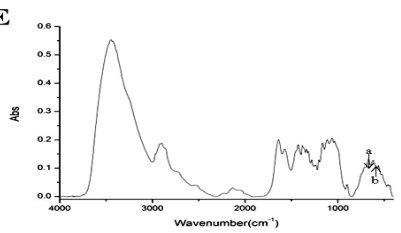

G
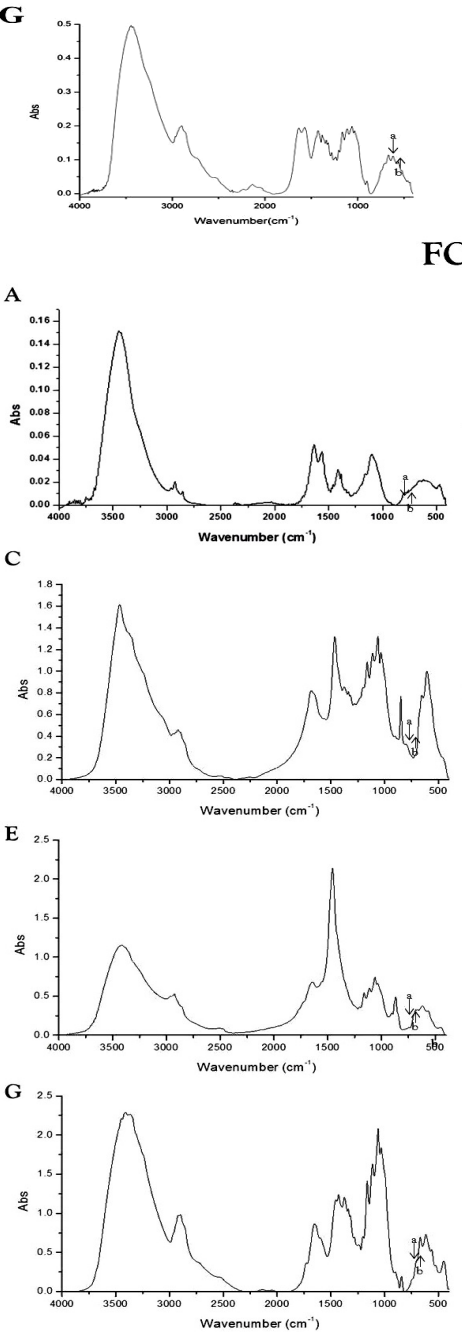

B

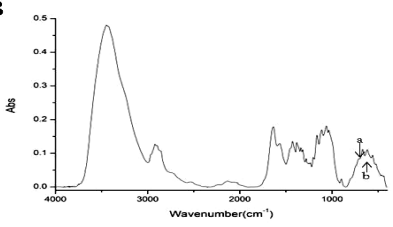

D

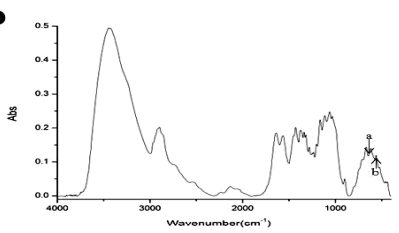

F

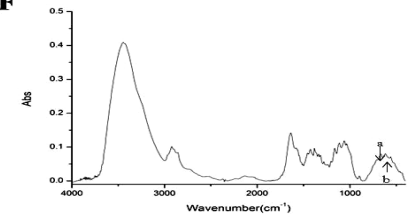

\section{FCW}

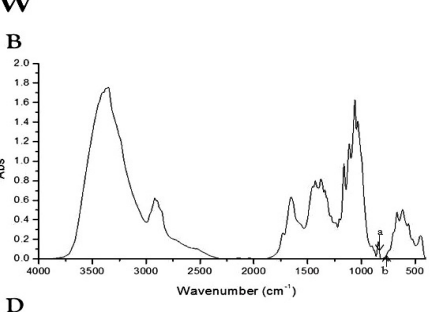

$\mathrm{D}$

Figure 5: FT-IR spectra of BCs without Congo red staining prepared in agitated culture in HS (left) and FCW (right) media from day 1 to day 7 (A to G, respectively);

$$
\mathrm{I}_{\alpha}\left(\mathrm{a}: 750 \mathrm{~cm}^{-1}\right) \text { and } \mathrm{I}_{\beta}\left(\mathrm{b}: 710 \mathrm{~cm}^{-1}\right)
$$


Sheykhnazari et al. found the hydrogen and $\mathrm{C}-\mathrm{H}$ bonds developed with the increase in the growth time. ${ }^{29}$ Our results showed the solid sphere-like $\mathrm{BC}$ had the same $\mathrm{I}_{\alpha}$ mass fraction. The FT-IR results regarding the cellulose $\mathrm{I}_{\alpha}$ content agreed with the findings of the X-ray diffraction investigation. Yamamoto et al. suggested that thermodynamically stable $I_{\beta}$ cellulose was produced under less stress conditions, while the crystallization of $\mathrm{I}_{\alpha}$ cellulose occurs under the influence of shearing stress. The grown sphere-like BC may induce a less stress condition by preventing the aggregation of microfibrils to a ribbon. The decrease of the shearing force during the process of sphere-like BC formation may be a factor for the formation of intra- and inter-molecular hydrogen bonds in sub-elementary cellulose fibrils, which disturbed their aggregation and crystallization. So, the prepared solid sphere-like $\mathrm{BC}$ had $\mathrm{I}_{\beta}$ dominant type and higher crystallinity. The content of $\mathrm{I}_{\alpha}$ decreased gradually over time and the BC particles from HS had higher content of $\mathrm{I}_{\alpha}$ than those from FCW. Meanwhile, the content of $\mathrm{I}_{\beta}$ increased gradually. Previous studies reported the production of cellulose spheres by Acetobacter xylinum NQ5 (ATCC 53582) in flasks at different rotational speeds (in the range of $90-250 \mathrm{rpm}$ ). ${ }^{42}$ Yan et al. used Acetobacter xylinum 1.1812 at a rotational speed of $150 \mathrm{rpm}$ to obtain snow-like $\mathrm{BC}$, whose $\mathrm{I}_{\alpha}$ content was $37.46 \%$ and CI was $2.23 .^{30}$ Aydin et al. used Gluconacetobacter hansenii $\mathrm{P} 2 \mathrm{~A}$ to obtain a series of $\mathrm{I}_{\alpha}$ mass fractions of $0.88,0.81$ and 0.79 for static, shaken and agitated cultivation conditions, respectively. ${ }^{43}$ Several studies demonstrated that there was higher cellulose $\mathrm{I}_{\alpha}$ content in the static culture BCs compared with that in agitated culture. ${ }^{30,43}$

\section{Thermogravimetric analysis}

To determine the thermal decomposition behavior of the $\mathrm{BCs}$ prepared during different time periods in agitated culture, thermogravimetric analysis (TGA) was performed on the BC samples. ${ }^{27}$ The maximum decomposition temperature $\left(T_{\max }\right)$, known as a criterion of thermal decomposition, was calculated from different TGA curves. Each peak on the $T_{\max }$ pattern represents the steepest slope of weight loss $\left(\% /{ }^{\circ} \mathrm{C}\right)$ for each step during decomposition, indicating the possibility of a type of decomposition. ${ }^{28}$ Figure 6 and Table 3 indicate single step degradations, with maximum decomposition temperatures of $316.92,320.71$, $322.48,323.12,329.77,329.86$ and $339.08{ }^{\circ} \mathrm{C}$ for the $\mathrm{BC}$ prepared in HS on day 1 to day 7, respectively. Meanwhile, the BCs produced in FCW medium reached maximum decomposition temperatures of $305.07,306.68,320.97,325.33$, $328.80,330.02$ and $334.44{ }^{\circ} \mathrm{C}$ (for day 1 to day 7 , respectively).

The thermal stability increased and the maximum decomposition temperature $\left(T_{\max }\right)$ enhanced over time and the $\mathrm{BC}$ particles from HS reached higher values than those from FCW. Yang and Chen established that an initial weight loss at lower temperatures, ranging from $200{ }^{\circ} \mathrm{C}$ to 360 ${ }^{\circ} \mathrm{C}$, can be attributed to the loss of small molecular groups, such as hydroxyl and methylhydroxyl groups. ${ }^{44}$ The thermal degradation behavior was affected by some structure parameters, such as molecular weight, $\mathrm{I}_{\beta}$ content and crystallinity. ${ }^{45}$ The thermal stability increased with the course of time, which confirmed the gradual increase in the $\mathrm{I}_{\beta}$ phase content and crystallinity, indicating that the achieved solid sphere-like BC possessed high thermal stability and began to degrade at higher temperature. 
Bacterial cellulose

HS

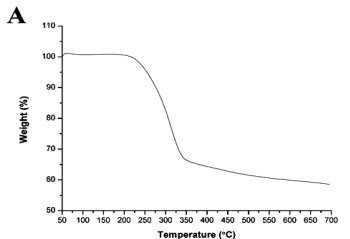

C
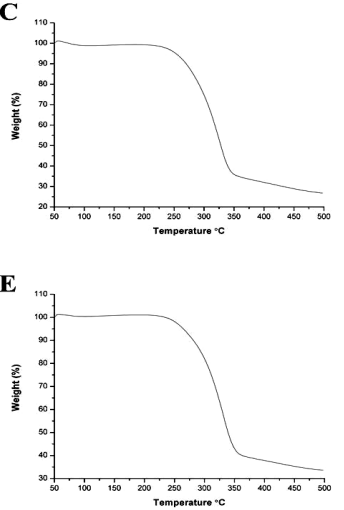

G

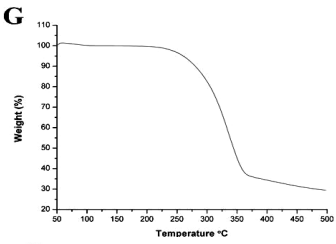

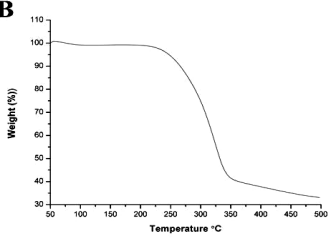

D
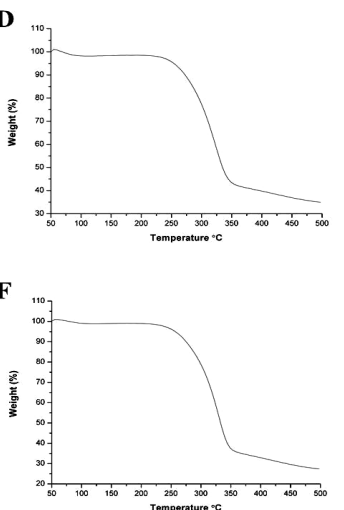

FCW
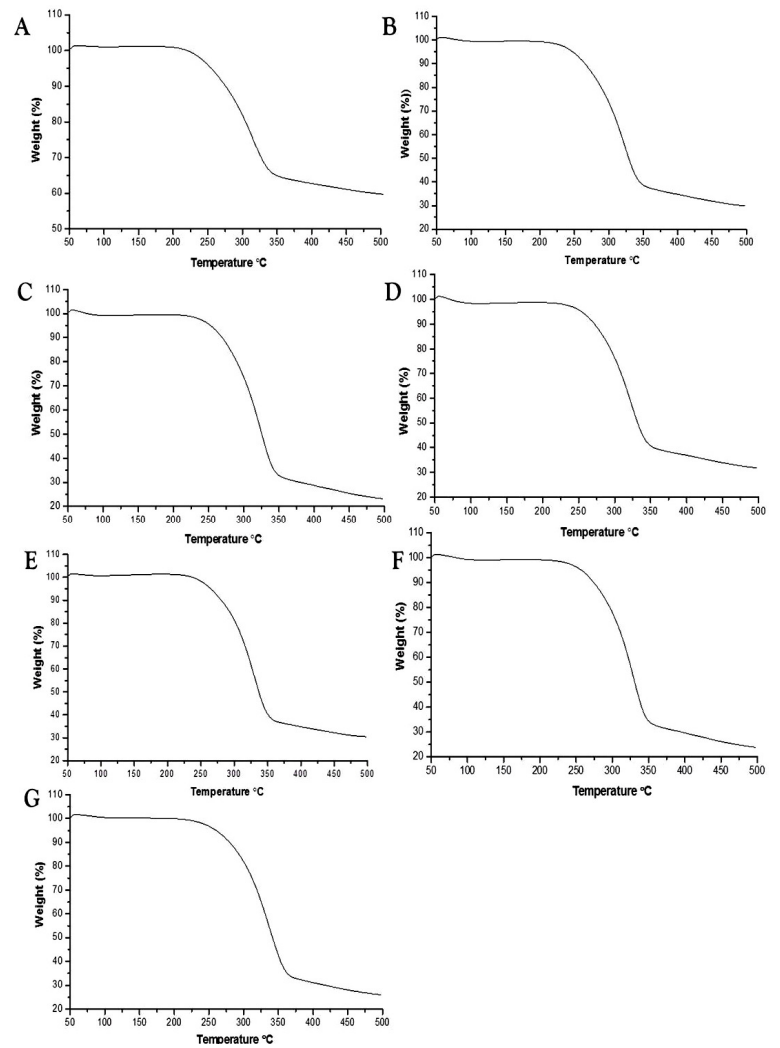

Figure 6: TGA curves of BCs without Congo red staining prepared in agitated culture in HS (left) and FCW (right) media from day 1 to day 7 (A to G, respectively) 
JICAI BI et al.

Table 3

TGA results of BCs without Congo red staining prepared in agitated culture in HS and FCW media from day 1 to day 7

\begin{tabular}{lccc}
\hline Samples & $T_{i}\left({ }^{\circ} \mathrm{C}\right)$ & $T_{\max }\left({ }^{\circ} \mathrm{C}\right)$ & $T_{f}\left({ }^{\circ} \mathrm{C}\right)$ \\
\hline BC- $1^{\text {st }}$ day (HS) & 259.81 & 316.92 & 339.97 \\
BC- $2^{\text {nd }}$ day (HS) & 274.58 & 320.71 & 341.72 \\
BC- $3^{\text {rd }}$ day (HS) & 278.21 & 322.48 & 341.72 \\
BC-4 $4^{\text {th }}$ day (HS) & 277.69 & 323.12 & 341.75 \\
BC- $5^{\text {th }}$ day (HS) & 284.96 & 329.77 & 348.79 \\
BC- $6^{\text {th }}$ day (HS) & 286.39 & 329.86 & 345.60 \\
BC- $7^{\text {th }}$ day (HS) & 287.34 & 339.08 & 359.57 \\
BC- $1^{\text {st }}$ day (FCW) & 231.66 & 305.07 & 336.67 \\
BC- $2^{\text {nd }}$ day (FCW) & 232.07 & 306.68 & 352.66 \\
BC- $3^{\text {rd }}$ day (FCW) & 236.07 & 320.97 & 356.73 \\
BC- $4^{\text {th }}$ day (FCW) & 237.23 & 325.33 & 362.62 \\
BC- $5^{\text {th }}$ day (FCW) & 241.13 & 328.80 & 367.35 \\
BC- $6^{\text {th }}$ day (FCW) & 246.50 & 330.02 & 372.08 \\
BC- $7^{\text {th }}$ day (FCW) & 250.76 & 334.44 & 376.97 \\
\hline
\end{tabular}

$T_{i}$ - initial temperature of decomposition; $T_{\max }-$ temperature of maximum decomposition; $T_{f} \quad$ - final temperature of decomposition

\section{CONCLUSION}

Here, we used $K$. nataicola Y19 to produce sphere-like $\mathrm{BC}$ in agitated culture and then characterized it. Two kinds of BCs were obtained and their morphology changed from filamentous $\mathrm{BC}$ on the $1^{\text {st }}$ day of the formation process to final solid sphere-like BC on the $7^{\text {th }}$ day. Accordingly, the size of internal pores decreased gradually, while the degree of crystallinity increased constantly from $80.44 \%$ to $88.23 \%$ (HS) or from $66.11 \%$ to $83.53 \%$ (FCW). Also, during the seven days of the formation process, the content of $I_{\alpha}$ in the $\mathrm{BC}$ decreased gradually from $76.63 \%$ to $70.84 \%$ (HS) or from $70.69 \%$ to $55.74 \%$ (FCW), while that of $I_{\beta}$ increased. Finally, the thermal stability of the produced BCs increased over time and the maximum decomposition temperature $\left(T_{\max }\right)$ increased from $316.92^{\circ} \mathrm{C}$ to $339.08^{\circ} \mathrm{C}$ (HS) and from $305.07{ }^{\circ} \mathrm{C}$ to $334.44{ }^{\circ} \mathrm{C}$ (FCW).

ACKNOWLEDGEMENTS: This work was supported by NSFC Regional Science Foundation Project (31660458) and High Level Talents Program of Hainan Natural Science Foundation (2019RC083).

\section{REFERENCES}

1 N. Yin, R. Du, F. Zhao, Y. Han and Z. Zhou, Carbohyd. Polym., 229, $115520 \quad$ (2020), https://doi.org/10.1016/j.carbpol.2019.115520

2 E. E. Brown and M. P. Laborie, Biomacromolecules, 8, 3074 (2007), https://doi.org/10.1021/bm700448x
3 Y. Yamada, Int. J. Syst. Evol. Microbiol., 64, 5 (2014), https://doi.org/10.1099/ijs.0.054494-0

4 X. Zou, S. Zhang, L. Chen, J. Hu and F. F. Hong, Microb. Biotechnol., 13, 458 (2019), https://doi.org/10.1111/1751-7915.13494

5 P. Ross, R. Mayer and M. Benziman, Annu. Rev. Biochem., $\quad \mathbf{8 4}, \quad 95 \quad$ (2015), https://doi.org/10.1146/annurev-biochem-060614-0339 30

6 N. Shah, M. Ul-Islam, W. A. Khattak and J. K. Park, Carbohyd. Polym., 98, $1585 \quad$ (2013), https://doi.org/10.1016/j.carbpol.2013.08.018

7 V. Yadav, L. Sun, B. Panilaitis and D. L. Kaplan, J. Tissue Eng. Regen. Med., 9, E276 (2013), https://doi.org/10.1002/term.1644

${ }^{8}$ C. Zhu, F. Li, X. Zhou, L. Lin and T. Zhang, J. Biomed. Mater. Res. A, 102, 1548 (2013), https://doi.org/10.1002/jbm.a.34796

9 V. T. Nguyen, B. Flanagan, M. J. Gidley and G. A. Dykes, Curr. Microbiol., 57, 449 (2008), https://doi.org/10.1007/s00284-008-9228-3

10 C. Campano, N. Merayo, C. Negro and A. Blanco, Int. J. Biol. Macromol., 118, 1532 (2018), https://doi.org/10.1016/j.ijbiomac.2018.06.201

11 Y. Hu and J. M. Catchmark, Biomacromolecules, 11, 1727 (2010), https://doi.org/10.1021/bm100060v

12 K. Y. Lee, G. Buldum, A. Mantalaris and A. Bismarck, Macromol. Biosci., 14, 10 (2013), https://doi.org/10.1002/mabi.201300298

13 A. Tholen and A. Brune, Environ. Microbiol., 2, 436 (2000), https://doi.org/10.1046/j.1462-2920.2000.00127.x 14 A. C. Rodrigues, A. I. Fontao, A. Coelho, M. Leal, F. A. G. Soares da Silva et al., New Biotechnol., 49, 19 
(2019), https://doi.org/10.1016/j.nbt.2018.12.002

15 H. Toyosaki, T. Naritomi, A. Seto, M. Matsuoka, T.

Tsuchida et al., Biosci. Biotech. Biochem., 59, 1498 (1995), https://doi.org/10.1271/bbb.59.1498

16 S. Hestrin and M. Schramm, Biochem. J., 58, 345 (1954), https://doi.org/10.1042/bj0580345

17 B. V. Mohite, B. K. Salunke and S. V. Patil, Appl. Biochem. Biotechnol., 169, $1497 \quad$ (2013), https://doi.org/10.1007/s12010-013-0092-7.

18 H. Bai, X. Wang, Y. Zhou and L. Zhang, Prog. Nat.

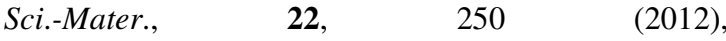
https://doi.org/CNKI:SUN:ZKJY.0.2012-03-015

19 J.-P. Touzel, B. Chabbert, B. Monties, P. Debeire and B. Cathala, J. Agric. Food. Chem., 51, 981 (2003), https://doi.org/10.1021/jf020200p

20 Q. Shi, Y. Li, J. Sun, H. Zhang, L. Chen et al., Biomaterials, 33, $6644 \quad$ (2012), https://doi.org/10.1016/j.biomaterials.2012.05.071

${ }_{21}$ H. Yamamoto, F. Horii and A. Hirai, Cellulose, 3, 229 (1996), https://doi.org/10.1007/BF02228804

22 L. Segal, J. Creely, A. Martin and C. Conrad, Text. Res. J., 29, $786 \quad$ (1959), https://doi.org/10.1177/004051755902901003

23 A. Mihranyan, A. P. Llagostera, R. Karmhag, M. Strømme and R. Ek, Int. J. Pharm., 269, 433 (2004), https://doi.org/10.1016/j.ijpharm.2003.09.030

24 K.-C. Cheng, J. M. Catchmark and A. Demirci, J. Biol. $\quad$ Eng., $\quad 3, \quad 12 \quad$ (2009), https://doi.org/10.1186/1754-1611-3-12

${ }_{25}^{25}$ Y. A. Aydin and N. D. Aksoy, Appl. Microbiol. Biotechnol., $\quad 98, \quad 1065$ (2013), https://doi.org/10.1007/s00253-013-5296-9

26 J. R. Colvin and D. Witter, Protoplasma, 116, 34 (1983), https://doi.org/10.1007/BF01294228

27 K.-C. Cheng, PhD Thesis, Pennsylvania State University, 2010, p. 102, https://etda.libraries.psu.edu/catalog/10894

${ }^{28}$ R. Bodîrlău and C. Teacă, in Procs. $8^{\text {th }}$ International Balkan Workshop on Applied Physics, 2009, p. 5, https://doi.org/10.1186/s13068-016-0623X

29 S. Sheykhnazari, T. Tabarsa, A. Ashori, A. Shakeri and M. Golalipour, Carbohyd. Polym., 86, 1187 (2011), https://doi.org/110.1016/j.carbpol.2012.05.060

${ }^{30}$ Z. Yan, S. Chen, H. Wang, B. Wang and J. Jiang, Carbohyd. Polym., 74, $659 \quad$ (2008), https://doi.org/10.1016/j.carbpol.2008.04.028
31 Y. S. Yun, H. Bak, S. Y. Cho and H. J. Jin, J. Nanosci. Nanotechnol., 11, $806 \quad$ (2011), https://doi.org/10.1166/jnn.2011.3182

32 M. Abba, Z. Ibrahim, C. S. Chong, N. A. Zawawi, M. R. A. Kadir et al., Fiber. Polym., 20, 2025 (2019), https://doi.org/10.1007/s12221-019- 9076-8

33 I. Sulaeva, H. Hettegger, A. Bergen, C. Rohrer, M. Kostic, J. Konnerth and A. Potthast,. Mat. Sci. Eng.: C, 3, 110619 (2020), https:// doi.org/ 10.1016/j.msec.2019. 110619

34 R. Salihu, C. Y. Foong, S. I. A. Razak, M. R. A. Kadir, A. H. M. Yusof et al., Cellulose Chem. Technol., 53, 13 (2019), https://doi.org/10.35812/Cellulose ChemTechnol.2019.53.01

35 A. Jalal Uddin, J. Araki and Y. Gotoh, Biomacromolecules, $12, \quad 617 \quad$ (2011), https://doi.org/10.1021/bm101280f

36 J. Mulligan and M. Cakmak, Macromolecules, 38, 2333 (2005), https://doi.org/10.1021/ma048794f

37 Y. W. Han and C. D. Callihan, Appl. Microbiol., 27, 165 (1974), https://doi.org/10.0000/PMID4809907

38 L. L. Zhou, D. P. Sun, L. Y. Hu, Y. W. Li and J. Z. Yang, J. Ind. Microbiol. Biotechnol., 34, 483 (2007), https://doi.org/10.1007/s10295-007-0218-4

${ }^{39}$ L. L. Zhou, D. P. Sun, Q. H. Wu, J. Z. Yang and S. L. Yang, Acta Microbiol. Sin., 47, 914 (2007), https://doi.org/10.13343/j.cnki.wsxb.2007.05.012

40 A. Kljun, T. A. Benians, F. Goubet, F. Meulewaeter, J. P. Knox et al., Biomacromolecules, 12, 4121 (2011), https://doi.org/10.1021/bm201176m

41 J. Gu and J. M. Catchmark, Carbohyd. Polym., 88, 547

https://doi.org/10.1016/j.carbpol.2011.12.040

${ }^{42}$ W. Czaja, D. Romanovicz and R. M. Brown, Cellulose, 11, 403 (2004), https://doi.org/10.1023/b:cell.0000046412.11983.61

43 Y. A. Aydin and N. D. Aksoy, Appl. Microbiol. Biot., 98, 1065 (2013), https://doi.org/10.1007/s00253-013-5296-9

44 J. Bi, S. Liu, C. Li, J. Li, L. Liu et al., J. Appl. Microbiol., $\quad 117, \quad 1311 \quad$ (2014), https://doi.org/10.1111/jam.12619

45 I. C. Um, C. S. Ki, H. Y. Kweon, K. G. Lee, D. W. Ihm et al., Int. J. Biol. Macromol., 34, 119 (2004), https://doi.org/10.1016/j.ijbiomac.2004.03.011 